University of Nebraska - Lincoln

DigitalCommons@University of Nebraska - Lincoln

Roman L. Hruska U.S. Meat Animal Research

U.S. Department of Agriculture: Agricultural Center

Research Service, Lincoln, Nebraska

2013

\title{
Environmental, social, and economic footprints of current and past beef production systems
}

\author{
K.R. Stackhouse-Lawson \\ National Cattlemen's Beef Association \\ J. O. Reagan \\ National Cattlemen's Beef Association \\ B. J. Isenberg \\ USDA-ARS \\ E. J. Pollak \\ USDA-ARS-NPA, jpollak2@unl.edu \\ T. Battagliese \\ BASF Corporation
}

See next page for additional authors

Follow this and additional works at: https://digitalcommons.unl.edu/hruskareports

Stackhouse-Lawson, K.R.; Reagan, J. O.; Isenberg, B. J.; Pollak, E. J.; Battagliese, T.; Ulhman, B.; Barcan, C.; Schulze, I.; Silva, J.; and Rotz, C. A., "Environmental, social, and economic footprints of current and past beef production systems" (2013). Roman L. Hruska U.S. Meat Animal Research Center. 428.

https://digitalcommons.unl.edu/hruskareports/428

This Article is brought to you for free and open access by the U.S. Department of Agriculture: Agricultural Research Service, Lincoln, Nebraska at DigitalCommons@University of Nebraska - Lincoln. It has been accepted for inclusion in Roman L. Hruska U.S. Meat Animal Research Center by an authorized administrator of DigitalCommons@University of Nebraska - Lincoln. 


\section{Authors}

K.R. Stackhouse-Lawson, J. O. Reagan, B. J. Isenberg, E. J. Pollak, T. Battagliese, B. Ulhman, C. Barcan, I. Schulze, J. Silva, and C. A. Rotz 


\title{
Environmental, social, and economic footprints of current and past beef production systems
}

\author{
K.R. Stackhouse-Lawson ${ }^{1}$, J.O. Reagan ${ }^{1}$, B.J. Isenberg' ${ }^{2}$, E.J. Pollak ${ }^{3}$, T. Battagliese ${ }^{4}$, B. Ulhman ${ }^{4}$, \\ C. Barcan ${ }^{4}$, I. Schulze ${ }^{5}$, J. Silva ${ }^{5}$ and C.A. Rotz ${ }^{2}$ \\ ${ }^{1}$ National Cattlemen's Beef Association, Centennial, CO 80112, USA; kstackhouse@beef.org \\ ${ }^{2}$ USDA-ARS, Pasture Systems and Watershed Management Research Unit, University Park, PA \\ 16802, USA \\ ${ }^{3}$ USDA-ARS-NPA, Roman L. Hruska U.S. Meat Animal Research Center, Clay Center, NE 68933, USA \\ ${ }^{4}$ BASF Corporation, Nutrition and Health, Florham Park, NJ 07932, USA \\ ${ }^{5}$ BASF Corporation, Fundação Espaço ECO, 09844-900 Sao Bernardo do Campo, Brazil
}

\section{Introduction}

The beef industry has defined sustainability as meeting the growing demand for beef by balancing environmental responsibility, economic opportunity, and social diligence. Measuring sustainability is challenging, as the beef supply chain is one of the most complex food systems in the world. As the first and largest research project of this kind, this study represents an innovative approach toward creating a more sustainable beef product. Our objective is to establish a sustainability baseline (including environmental, economic, and social footprints) for the US beef industry by quantifying life cycle inputs and outputs for beef production over time.

\section{Material and methods}

To determine the sustainability of beef production, a combination of models were used. The USDAARS Integrated Farm System Model (IFSM) was used to simulate environmental and economic footprints from cradle to farm-gate. The socio-eco-efficiency tool (SEEBALANCE ${ }^{\circledR}$ ) extends this analysis by determining the environmental, economic, and social impacts of beef from cradle to grave providing a comprehensive assessment of sustainability.

The IFSM is a process-level farm model that simulates crop growth, feed production and use, animal growth, and returning manure nutrients to the land to predict the environmental impacts and economics of agriculture production systems (Rotz et al., 2005). For the current study, relevant information for the US Meat Animal Research Center (USMARC) beef operation was gathered and used to establish model parameters. The USMARC farm, cow-calf and feedlot operations were simulated to evaluate performance, environmental impact and economics.

The environmental impacts and economics of beef production at the USMARC were combined with primary data from the packer, case ready, retail, and consumer segments of the beef value chain for 2005 and 2011 using SEEBALANCE ${ }^{\circledR}$. The SEEBALANCE ${ }^{\circledR}$ analysis includes environmental, social, and economic considerations as determined by method of life cycle analysis (Kölsh et al., 2008). This approach quantified US beef sustainability considering economic, social and ecological impacts along all segments of the beef value chain.

\section{Results and discussion}

\section{Integrated farm system model: USMARC}

A 25-year simulation of the USMARC's current production system gave a carbon footprint of 11 $\mathrm{kg}$ of $\mathrm{CO}_{2} \mathrm{e}$ per $\mathrm{kg}$ of live weight sold, which is consistent with other experiments (Johnson et al., 2003; Capper, 2011; Stackhouse-Lawson et al., 2012). The energy required to produce that beef (energy footprint) was $25.9 \mathrm{MJ} / \mathrm{kg}$. The total water required (water footprint) was $21,300 \mathrm{l} / \mathrm{kg}$ of 
live weight sold, and the water footprint excluding that obtained through precipitation was 2,800 $\mathrm{l} /$ $\mathrm{kg}$. The simulated total cost of producing their beef was about $\$ 2.20 / \mathrm{kg}$ of live weight sold, which agreed with USMARC production records.

\section{SEEBALANCE ${ }^{\circledR}$}

Table 1 quantifies the environmental, social and economic considerations of the beef supply chain expressed in $0.45 \mathrm{~kg}$ of minimally processed boneless edible consumed beef (UB). Overall, the sustainability of the US beef industry, given the present assumptions, has improved by $7 \%$ in $6 \mathrm{yr}$.

Table 1. Environmental, social and economic sustainability indicators for the beef supply chain.

\begin{tabular}{|c|c|c|c|}
\hline Sustainability indicators & 2005 & 2011 & $\%$ change \\
\hline \multicolumn{4}{|l|}{ Economic (expressed per $\mathrm{UB}^{1}$ ) } \\
\hline Consumer price $(\$)$ & 5.24 & 5.55 & 6 \\
\hline \multicolumn{4}{|l|}{ Environmental (expressed per UB) } \\
\hline Energy use (MJ) & 521 & 511.0 & -2 \\
\hline Resource consumption (mg silver ${ }_{e}$ ) & 5.05 & 4.96 & -2 \\
\hline Water consumption $(\mathrm{L})$ & 2,418 & 2,336 & -3 \\
\hline Solid waste (kg municipal waste ${ }_{e}$ ) & 0.19 & 0.18 & -7 \\
\hline Greenhouse gases $\left(\mathrm{kg} \mathrm{CO}_{2} e\right)$ & 23.7 & 23.6 & -1 \\
\hline Photochemical ozone creation potential $\left(\mathrm{g} \mathrm{C}_{2} \mathrm{H}_{4} e\right)$ & 0.026 & 0.026 & 0 \\
\hline Acidification potential $\left(\mathrm{g} \mathrm{SO}_{2} e\right)$ & 336 & 327 & -3 \\
\hline Ozone depletion potential (g CFCe) & 0.013 & 0.013 & 0 \\
\hline Water emissions (grey water (l diluted water ${ }_{e}$ ) & 4,981 & 4,487 & -10 \\
\hline Land use $\left(\mathrm{m}^{2} \mathrm{a}\right)$ & 21.4 & 20.5 & -4 \\
\hline \multicolumn{4}{|l|}{ Social (normalized and weighted ${ }^{2}$ ) } \\
\hline Occupation illnesses and accidents & 0.90 & 0.60 & -32 \\
\hline Toxicity potential & 1.00 & 0.84 & -16 \\
\hline
\end{tabular}

${ }^{1}$ User benefit (UB) $0.45 \mathrm{~kg}$ of minimally processed boneless edible consumed beef.

${ }^{2}$ Social indicators are normalized and weighted based on severity of incident or chemical.

\section{References}

Capper, J.L, 2011. Replacing rose-tinted spectacles with a high-powered microscope: The historical vs. modern carbon footprint of animal agriculture. Anim. Front. 1, 26-32.

Johnson, D. E., H. W. Phetteplace, A. F. Seidl, U. A. Schneider, and B. A. McCarl, 2003. Management variations for us beef production systems: Effects of greenhouse gas emissions and profitability. Proc. 3rd Int. Methane and Nitrous Oxide Mitigation Conf., Bejing China. 953-961.

Kölsh, D., P Saling, A. Kircherer, A. Grosse-Sommer, and I. Schmidt, 2008. How to measure social impacts? A socioeco-efficiency analysis by the SEEBALANCE ${ }^{\circledR}$ method. Int. J. Sustainable Development. 11, 1-23.

Rotz, C.A., D.R, Buckmaster, and J.W. Comerford, 2005. A beef herd model for simulation of feed intake, animal performance, and manure excretion in farm systems. J. Anim. Sci. 38, 231-242.

Stackhouse-Lawson, K.R., C.A. Rotz, J.W. Oltjen, and F.M. Mitloehner, 2012. Carbon footprint and ammonia emission of California beef production systems. J. Anim. Sci. 90, 4641-4655. 